\title{
Reproductive responses to varying food supply in a population of Darwin's finches: Clutch size, growth rates and hatching synchrony
}

\author{
Trevor Price \\ Division of Biological Sciences, The University of Michigan, Ann Arbor, MI 48109-1048, USA
}

\begin{abstract}
Summary. I show how food shortage affects reproduction in a population of Darwin's Medium Ground Finches, Geospiza fortis. Despite the common occurrence of starvation and absence of nest predation, hatching is typically highly synchronous and adaptive brood reduction appears to be absent. Variation in both growth rates and clutch size in association with the varying conditions is documented. This variation is interpreted as being a direct response to environmental conditions rather than adaptive phenotypic plasticity. I conclude that selection pressures to raise one or two chicks during times of food shortage, or to delay growth rates, are weak or absent.
\end{abstract}

Variation in clutch size, in growth rates and in the degree of hatching synchrony have often been discussed in terms of their possible adaptive significance in enabling one or more members of a brood to survive a period of food shortage during which the whole brood might otherwise starve (Ricklefs 1965, 1968; Lack 1968; O'Connor 1977). In contrast to these adaptive interpretations, variation in clutch size and in growth rates may be simple, non-adaptive, consequences of environmental conditions (Bryant 1978; Howe 1978; Horsfall 1984). Several alternative adaptive explanations, apart from responses to food supply, have been proposed for the presence of hatching asynchrony (Clark and Wilson 1981; Hahn 1981). In this paper I consider the way in which these characteristics change in response to variations in food supply in a population of Darwin's Medium Ground finches, Geospiza fortis, on I. Daphne Major in the Galápagos Islands. The population shows extreme variation in reproductive success. This is a consequence of the variable rainfall which in turn affects the availability of the food that finches eat (Grant and Boag 1980; Boag and Grant 1984). In 1978 only $24 \mathrm{~mm}$ of rain fell, and breeding completely failed (Boag and Grant 1984). At the other extreme, in 1983, 1,359 $\mathrm{mm}$ of rain fell, and breeding was very successful, with some pairs raising at least seven broods (Gibbs et al. 1984).

The observed multiple broods and their overlap in time (Boag and Grant 1984) are clearly adaptive responses enabling pairs to raise many offspring when food is abundant (cf. Grant and Grant 1980; Burley 1980). O'Connor (1977) has discussed the way in which the timing and predictability of food shortage might give rise to selection for clutch size or growth rate variation, or hatching asynchrony. First, if conditions at the time of egg-formation provide a good indication of those at the time when nestlings are being fed, clutch size may be adjusted so that the optimum number of nestlings are produced. Second, if conditions are largely unpredictable at the time of egg formation, but not highly variable during the nestling period, it is predicted that hatching will be asynchronous and broods will be reduced through the death of the smaller, later-hatched chicks. Finally, if conditions are both unpredictable and variable in the short term, a temporary slowing of growth preceded by fat storage may occur. These alternative strategies are not necessarily exclusive, and a combination may be favored by selection. For example, a modification of growth rates could allow a finer adjustment of the energy needs of a brood to the energy supply than would the loss or addition of whole chicks (Ricklefs 1968, 1976).

During my study, which lasted from 1979-1981, several pairs attempted to raise more than one brood only once (in late 1981, Price 1984 a). In contrast, during four periods many pairs failed to raise any young. I show how growth rates and clutch sizes varied in association with the different conditions, whereas hatching synchrony remained high. I use the results to argue for the absence of any strong selection pressure on parents to raise less than a full brood during times of food shortage.

\section{Methods}

Most of the methods used in this study, and a description of the island and its fauna and flora, can be found in Millington and Grant (1983, 1984) and Boag and Grant (1984). I spent most of the first six months of each year 1979-1981 on I. Daphne, and located active nests of $G$. fortis as they were being constructed. Clutch size, and hatching and fledging success, were recorded for all nests (Price 1984b). The incubation period for these finches is typically twelve days from the laying of the last egg, and fledging occurs 12-14 days after hatching (Boag and Grant 1984). The number of fledglings was usually known from direct observations, but in some instances in late 1979 and in 1981 these observations were lacking, and then the number of fledglings was taken to be the same as the number of 8 day old chicks in the nest, unless a chick was greatly underweight. Chicks were weighed (in g), measured (in $\mathrm{mm}$ ), and banded at age 7-9 days. Between 50 and 100 chicks each 

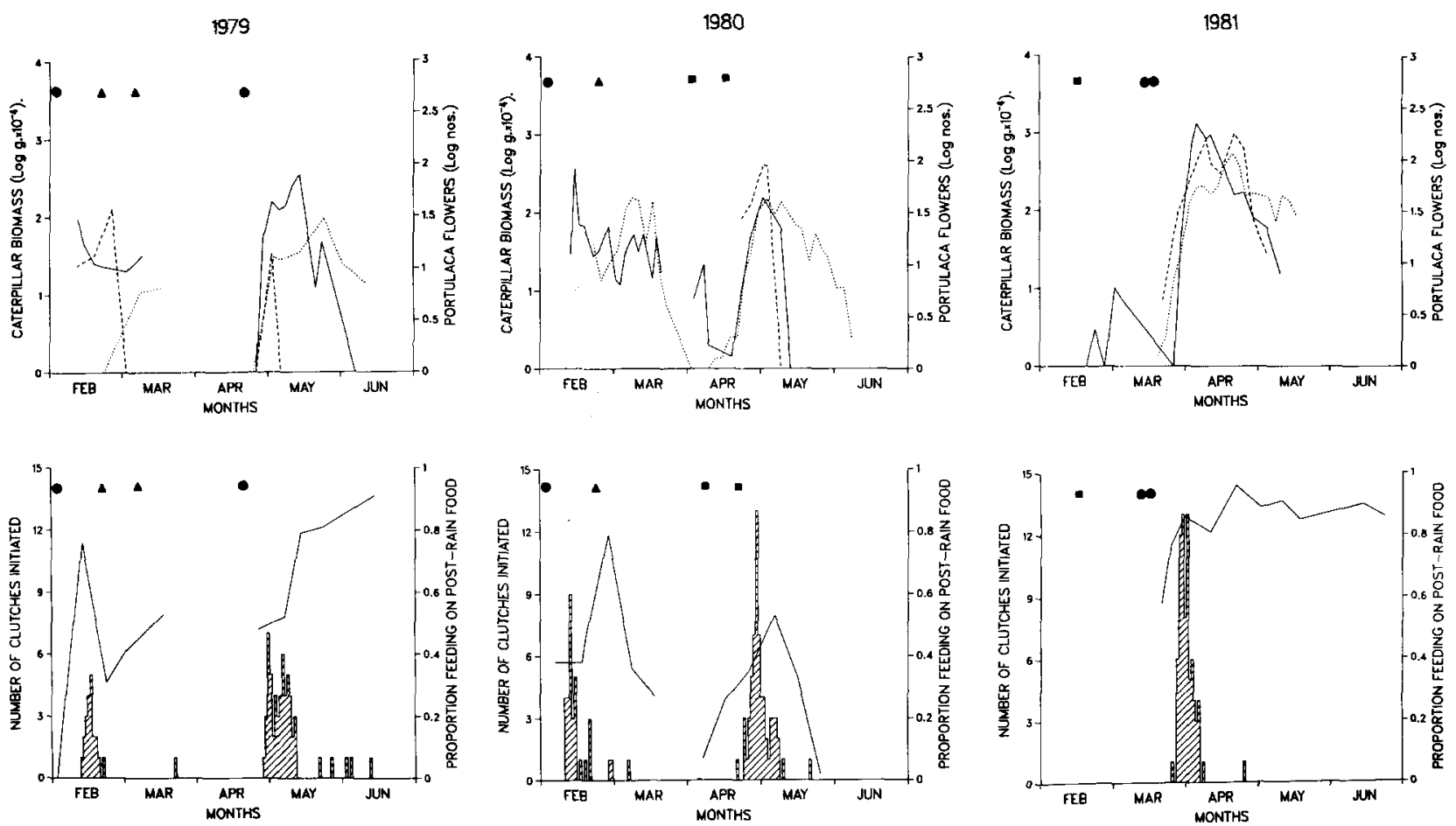

Fig. 1. Food supply, foraging and clutch initiations for each year 1979-1981. Above: biomass of caterpillars (dry weight) collected in $20 \mathrm{~min}$ searches of Bursera graveolens trees (-...) and Poriulaca howellii plants (-_ - , and the number of Portulaca flowers counted on 50 plants $(\cdots .$.$) . Numbers of Portulaca flowers are from Millington and Grant (1983). Below: first egg dates for first$ clutches in each breeding bout (שख) and the proportion of feeding observations that were on food that appeared in response to

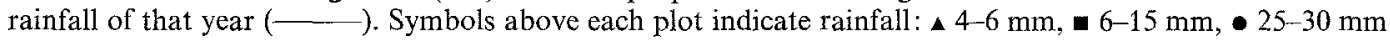

year were weighed and measured at two day or longer intervals from day 0 (hatching), 1 , or 2 , until 8 to 10 days old, or until they died. The measurements used here are beak depth, (measured at right angles to the beak commisure above the nares), and length of the fourth primary (including sheath, from the feather base to tip). Logistic growth equations, $y=A /(1+\exp (-k(x-t)))$, where $y$ is the character, $x$ the age in days, and $k, A$ and $t$ constants (e.g. Ricklefs 1979) were fitted to the growth data. I used the iterative program BMDPAR in BMDP to do this. Most of the parents of the chicks had been uniquely colour banded and measured (Price 1984b).

Flower pollen, caterpillars and small seeds are important items in the diet of nestlings and fledglings (Boag and Grant 1984). The availability of these foods was quantified by collecting caterpillars in random $20 \mathrm{~min}$ searches of vegetation types, by counting flowers of Portulaca howellii on 50 specific plants every day, and by counting seeds on plants in five $4 \mathrm{~m}^{2}$ plots every ten days. Caterpillars were saved in alcohol and dried and weighed in the laboratory. Observations of feeding behavior were made on a regular morning walk conducted at 10 day intervals over approximately two-thirds of the island; the first item of food consumed by each bird was recorded.

\section{Results}

\section{Food supply and breeding responses}

The Galápagos receive highly unpredictable amounts of rain, falling at low elevations almost entirely during the first six months of the year (Grant and Boag 1980). Finches

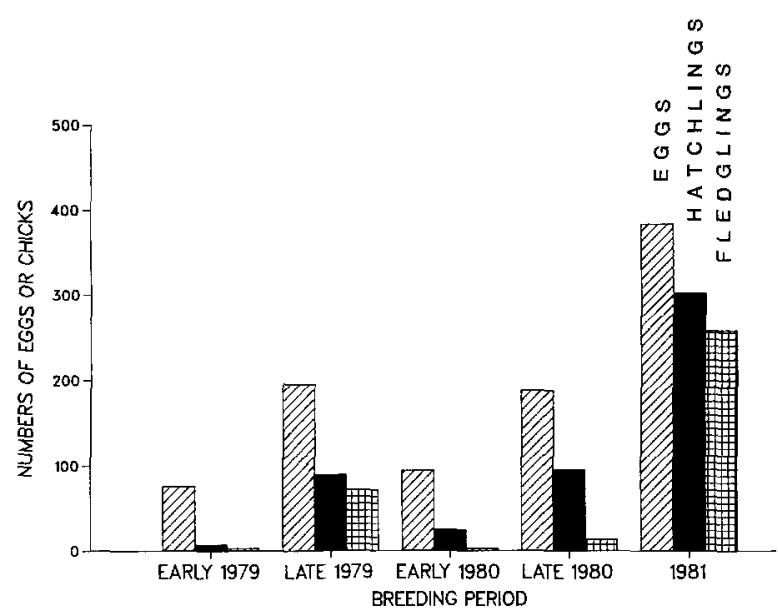

Fig. 2. The number of eggs (因), hatchlings ( $\mathbf{m}$ ) and fledglings (西) in each breeding period. The few nests in each period $(\sim 3)$ for which either eggs, or hatchlings or fledglings were not known are excluded. The number of fledglings was directly observed except for some nests in late 1979 and 1981 when it was taken to be the same as the number of 8 day old chicks, unless a chick was substantially underweight

start breeding within two weeks of the first rains (Fig. 1). During 1979-1981 rainfall was generally low, with annual totals of 69,54 and $80 \mathrm{~mm}$ respectively (Millington and Grant 1983; Fig. 1). It stimulated egg laying in five separate periods (Fig. 1); and there was additionally a period of singing and nest-building, but no egg-laying, in response to rain in February, 1981. Substantial numbers of chicks fledged from only two of these five periods (Fig. 2). 
Table 1. Clutch sizes for first clutches in each breeding period. Means, standard deviations and sample sizes (in parentheses) are given, separately for females born before 1976, and in 1978. No 1978-born females bred in early 1979

\begin{tabular}{|c|c|c|c|c|c|}
\hline & Early 1979 & Late 1979 & Early 1980 & Late 1980 & 1981 \\
\hline Pre-1976 females & $3.0 \pm 0.52(16)$ & $3.4 \pm 0.84(23)$ & $2.8 \pm 0.79(18)$ & $3.2 \pm 0.58(25)$ & $3.8 \pm 0.91(20)$ \\
\hline 1978 females & - & $2.8 \pm 0.80(22)$ & $2.4 \pm 0.92(11)$ & $2.9 \pm 0.65(28)$ & $3.9 \pm 0.82(36)$ \\
\hline
\end{tabular}

Table 2. Hatching asynchrony. The proportion of nests visited when chicks were 0-1 days old in which an egg had still to hatch (with the number of nests in parentheses), and variance in weight among hatched nestlings at $0-1$ days is given

\begin{tabular}{lll}
\hline Year & $\begin{array}{l}\text { Proportion of nests with } \\
\text { an egg which later hatched }\end{array}$ & $\begin{array}{l}\text { Variance in } \\
\text { Weight, log g }\end{array}$ \\
\hline 1979 & $0.52(29)$ & 0.089 \\
1980 & $0.45(16)$ & 0.056 \\
1981 & $0.50(18)$ & 0.135 \\
\hline
\end{tabular}

Nest predation has not been known to occur on the island. Therefore, breeding success can be related clearly to food supply (Fig. 1). In both successful breeding episodes over $90 \%$ of observed feedings were on food that was available as a direct result of the year's rainfall (Fig. 1), and nestling crops were full of caterpillars, Portulaca pollen and small seeds, all produced in response to the rain.

Variation in the relative abundance of caterpillars and Portulaca flowers through time is shown in Fig. 1. Small seed production is not shown: of the most common plants, Amaranthus sclerantoides and Boerhaavia erecta reached peak seed abundance 30-35 days after rain, Portulaca at least 45 days after rain.

The important observations for the purpose of this paper are (1) at the time of egg formation individuals are feeding substantially on rain-response foods, (2) there is a delay of from several days up to one month (in the case of the seeds of some plant species) before the different rainresponse foods become abundant and (3) during times of unsuccessful reproduction, food supply and foraging on rain response foods decline while chicks are still in the nest (Fig. 1).

Figure 2 shows the number of eggs, nestlings and fledglings in each period. Large numbers of clutches were deserted in all periods in 1979 and 1980. The majority of abandoned eggs contained chick embryos. The timing of desertions may be closely matched to a deterioration in the food supply. In late 1979 clutches were apparently deserted as caterpillars disappeared but before Portulaca flowers appeared. All the deserting females subsequently laid a second clutch, presumably in response to the resurgent food supply. In late 1979 most chicks fledged, but in late 1980 there was substantial chick mortality in the nest (Fig. 2).

\section{Variation in reproductive responses}

Chtch size. Most females were known to have been born before 1976 , or in 1978, so age-cohort membership can be identified and controlled for in comparisons of clutch sizes among years. Nearly all clutches were of three or four eggs. Therefore, I used $\chi^{2}$ tests and compared clutches of three
Table 3. Brood reduction among different-aged nestlings from ages 0 to 8 days. Nests included in the analysis are those in which more than two chicks hatched, and which were visited when the chicks were $0-1$ days old, approximately 4 days old, and again at approximately 8 days old. Nests which failed completely before age 8 days are totaled separately

\begin{tabular}{|c|c|c|c|c|c|}
\hline & \multicolumn{5}{|c|}{ Number of broods } \\
\hline & \multicolumn{2}{|c|}{$\begin{array}{l}\text { Partial brood } \\
\text { reduction }\end{array}$} & \multirow[t]{2}{*}{$\begin{array}{l}\text { No brood } \\
\text { reduction }\end{array}$} & \multirow{2}{*}{$\begin{array}{l}\text { Complete } \\
\text { nest } \\
\text { failure }\end{array}$} & \multirow[t]{2}{*}{ Total } \\
\hline & $<4$ days & $>4$ days & & & \\
\hline 1979 & 4 & 7 & 19 & 0 & 30 . \\
\hline 1980 & 3 & 6 & 4 & 4 & 17 \\
\hline 1981 & 2 & 3 & 19 & $\hat{1}$ & 25 \\
\hline
\end{tabular}

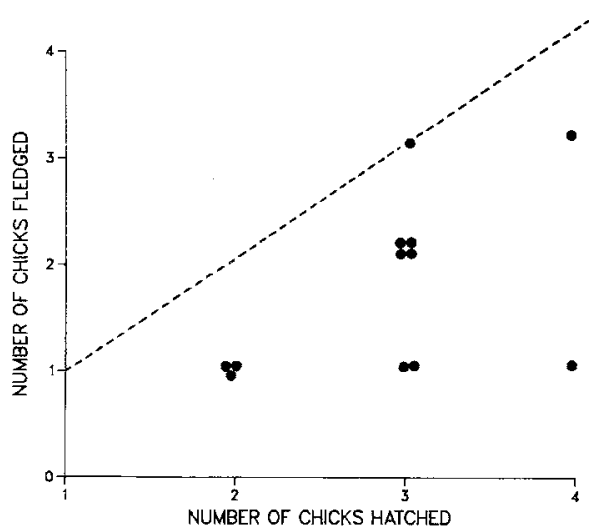

Fig. 3. Number of chicks fledged in relation to the number hatched from all broods fledging at least one young in early 1979 and in 1980. Dashed line indicates $100 \%$ fledging success

Table 4. Logistic growth curve parameters. $\mathrm{K}$ (in days ${ }^{-1}$ ) is a measure of growth rate, A (in $\mathrm{g}$ or $\mathrm{mm}$ ) is the asymptote. Only chicks first measured at 0 to 2 days old are included. Sample sizes are for the number of chicks measured until at least age day 6 , with the total number of measurements in parentheses

$\begin{array}{llll}\text { Late } 1979 & \text { Late } 1980 & 1981 & \text { Adult size } \\ \text { Mean } \pm \text { s.e. } & \text { Mean } \pm \text { s.e. } & \text { Mean } \pm \text { s.e. } & \begin{array}{l}\text { (appro- } \\ \text { ximate) }\end{array}\end{array}$

\begin{tabular}{lrlll}
\hline Weight & & & & \\
K & $0.42 \pm 0.03$ & $0.28 \pm 0.07$ & $0.46 \pm 0.03$ & \\
A & $15.84 \pm 0.62$ & $11.72 \pm 2.4$ & $15.83 \pm 0.42$ & $16.5 \mathrm{~g}$ \\
Beak depth & & & & \\
K & $0.22 \pm 0.02$ & $0.11 \pm 0.04$ & $0.23 \pm 0.02$ & \\
A & $6.33 \pm 0.24$ & $7.70 \pm 2.19$ & $6.71 \pm 0.21$ & $9.9 \mathrm{~mm}$ \\
Fourth primary & & & \\
K & $0.89 \pm 0.05$ & $0.72 \pm 0.10$ & - & \\
A & $23.28 \pm 0.67$ & $23.27 \pm 2.56$ & - & $60 \mathrm{~mm}$ \\
Sample size & $71(323)$ & $22(116)$ & $75(341)$ & \\
\hline
\end{tabular}



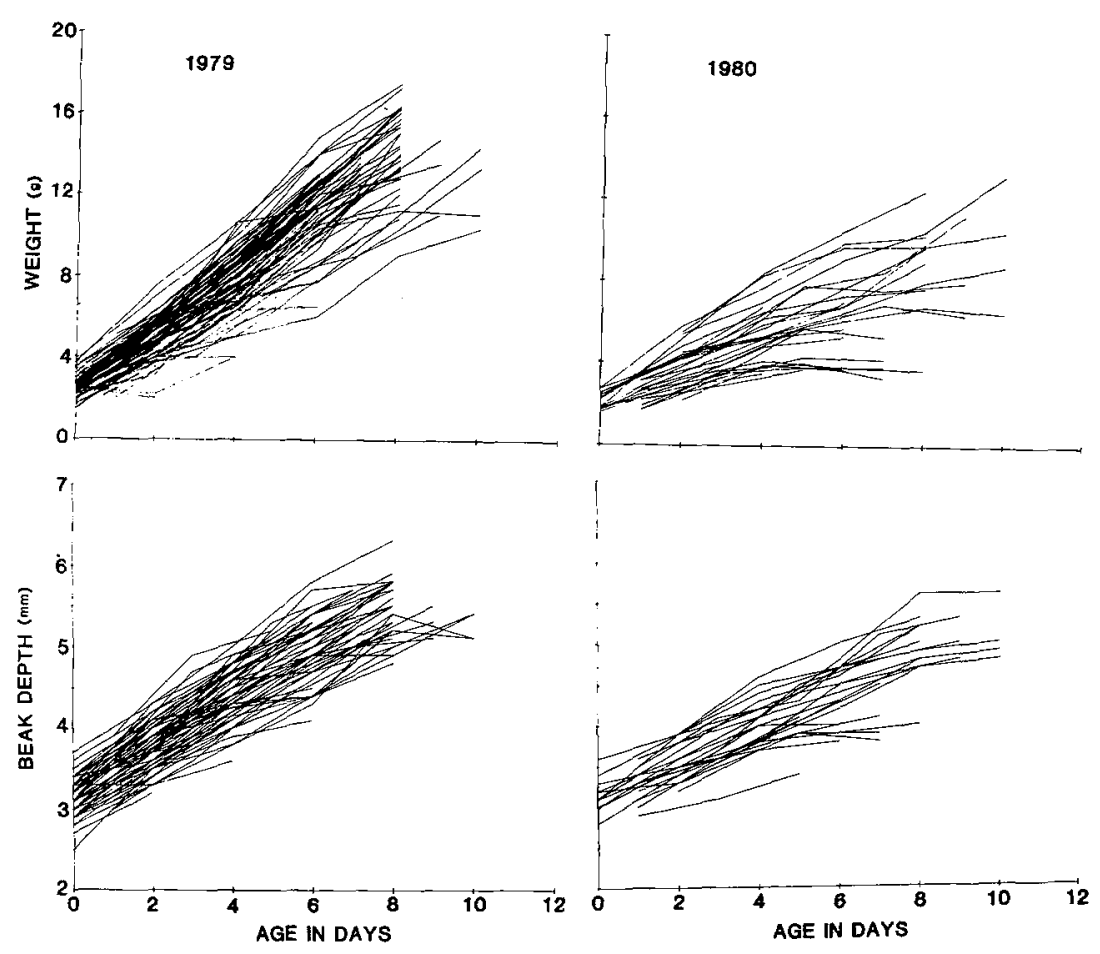

Fig. 4. Growth curves for the characters body weight and beak depth in late 1979 and late 1980. The curves for 1981 are very similar to those for 1979 or fewer eggs with those with four or more to test for differences among breeding episodes. These tests gave $\chi_{4}^{2}=26.2$, $P<0.001$ for pre-1976 females and $\chi_{3}^{2}=44.3, P<0.001$ for 1978 females), indicating significant variation in clutch size among periods (Table 1). This variation is not a function of different groups of females breeding at different times. For example, among the 19 females born before 1976 which laid eggs in late 1979, in late 1980, and also in 1981, mean first clutch sizes were $3.33,3.27$ and 3.74 respectively $\left(\chi_{2}^{2}=9.8, P<0.01\right)$.

Clutch size varies in association with rainfall and food supply. The largest clutches (including the only clutches with 5 eggs) were associated with the periods of high rainfall, large food supply, and successful breeding, in late 1979 and 1981 . The population was also studied in 1978 by Boag and Grant (1984) when there were three breeding periods. If I include these episodes in an analysis of clutch size variation among the pre-1976 females I find a significant correlation between the cumulative rainfall in each year and the mean clutch size in the breeding period $(r s=0.96, \mathrm{~N}=8$, $P<0.05)$.

Hatching synchrony. About half the nests visited when the oldest chick was 0-1 days old had at least one egg which later hatched, and this proportion did not vary among years $\left(\chi_{2}^{2}=0.28, P>0.9\right.$, Table 2$)$. This suggests that hatching is typically spread over about $24 \mathrm{~h}$, which is highly synchronous (Clark and Wilson 1981). There is almost no evidence for facultative asynchrony in poor years. In only one nest, in late 1980, was an egg known to have hatched more than $48 \mathrm{~h}$ after the first egg hatched. Variation in weight among chicks at first weighing actually appeared to be lower in the poor year of 1980 (Table 2) when facultative asychrony might have been most expected.

Brood reduction. Every nest but one that yielded fledglings in the periods of low reproductive success (early 1979 and all of 1980) fledged fewer young then were hatched, i.e. there was brood reduction (Fig. 3). None of the young fledged at these times survived for more than one month after fledging. Some brood reduction was also observed in 1981, when fledging success was high (Table 3).

Brood reduction occurred more commonly among older nestlings, when food requirements would be greatest. Only a few entire broods died before the chicks were 4 days old. Among 13 nests suffering partial brood reduction when the chicks were at least 4 days old, 12 lost the chick which was smallest at hatching, and only one lost a larger chick ( $P<0.01$, binomial test). However, loss of very young nestlings (1-3 days old) did not appear to be associated with size at hatching (from two nests the smallest at hatching died, from 4 others one of the larger ones died).

Growth. Chicks grew more slowly in the poor year of 1980 (Table 4; Fig. 4) than in the other two years. In 1980 body weight at day $7-8$ suffered a greater proportional decrease than beak depth, as shown by the differences of the logarithmic values (Table 5). The primaries showed the greatest proportional decrease; they grow late in development (Boag 1984), and are therefore more greatly affected by malnutrition in older nestlings.

Chick growth rates were much more variable in 1980 than in the other years (e.g. Fig. 4). Some chicks were able to maintain close-to-normal growth rates in 1980. Others survived long periods with stunted growth (Fig. 4) but none of these subsequently increased their growth rates. All chicks growing abnormally failed to survive for long, although a few did fledge in late 1980.

Growth in healthy chicks has a strong genetic component (Price and Grant 1985). This can be shown by calculating the covariance between chick and mid-parent, which provides an estimate of half the genetic covariance between the adult and juvenile character (Falconer 1981). The regression of chick values on mid-parent values, as the ratio 
Table 5. Measurement means \pm standard deviations for chicks at age 7-8 days, and the difference between the average values for 1979 and 1981, and 1980. $F$ statistic is based on a 1-way ANOVA among years. ${ }^{* *} P<0.01$

\begin{tabular}{|c|c|c|c|c|c|}
\hline & $\begin{array}{l}\text { Late } \\
1979\end{array}$ & $\begin{array}{l}\text { Late } \\
1980\end{array}$ & 1981 & $\begin{array}{l}\text { Differ- } \\
\text { ence }\end{array}$ & $F$ \\
\hline $\begin{array}{l}\sqrt[3]{\text { Weight }} \\
\log g\end{array}$ & $\begin{array}{l}0.86 \\
\pm 0.05\end{array}$ & $\begin{array}{l}0.71 \\
\pm 0.12\end{array}$ & $\begin{array}{l}0.81 \\
\pm 0.07\end{array}$ & 0.16 & $26.4^{* *}$ \\
\hline $\begin{array}{l}\text { Beak depth, } \\
\text { log mm }\end{array}$ & $\begin{array}{l}1.68 \\
\pm 0.06\end{array}$ & $\begin{array}{l}1.59 \\
\pm 0.11\end{array}$ & $\begin{array}{l}1.70 \\
\pm 0.08\end{array}$ & 0.10 & 55.1 ** \\
\hline $\begin{array}{l}\text { 4th Primary, } \\
\log \mathrm{mm}\end{array}$ & $\begin{array}{l}2.96 \\
\pm 0.40\end{array}$ & $\begin{array}{l}2.66 \\
\pm 0.14\end{array}$ & - & 0.30 & $12.5 * *$ \\
\hline Sample size & 54 & 34 & 189 & & \\
\hline
\end{tabular}

Table 6. Regressions of offspring measurements (family means) at age 7-8 days on mid-parent measurements. Sample size gives the number of chicks, with the number of families in parentheses. ${ }^{*} P<$ $0.05,{ }^{*} P<0.01$

\begin{tabular}{llll}
\hline & $\begin{array}{l}1979 \\
\beta \pm \text { s.e. }\end{array}$ & $\begin{array}{l}1980 \\
\beta \pm \text { s.e. }\end{array}$ & $\begin{array}{l}1981 \\
\beta \pm \text { s.e. }\end{array}$ \\
\hline $\begin{array}{l}\text { Weight, } \\
\text { log g }\end{array}$ & $0.83 \pm 0.33^{*}$ & $-0.61 \pm 1.52$ & $1.08 \pm 0.26^{* *}$ \\
$\begin{array}{l}\text { Beak depth, } \\
\text { log mm }\end{array}$ & $0.51 \pm 0.16^{* *}$ & $0.34 \pm 0.36$ & $0.65 \pm 0.14^{* *}$ \\
\begin{tabular}{l} 
Sample size \\
\hline
\end{tabular} & $52(32)$ & $34(13)$ & $160(50)$ \\
\hline
\end{tabular}

of the covariance to the variance of the mid-parent values, provides a simple way of visualizing changes in the covariance between offspring and parents in association with starvation (Table 6). In particular, a negative covariance would indicate a negative gentoype-environment covariance during periods of heavy mortality, i.e, that the genetically larger chicks were actually smaller than the genetically smaller chicks. In 1980 the covariances for both beak depth and weight were apparently reduced, and for weight it was (nonsignificantly) negative (Table 6). However, increased variance and reduced sample sizes in 1980 led to large standard errors for the estimates of the regression coefficients, and differences in the regression coefficients among years are not significant (ANCOVA, F $(2,90)=0.59, P=0.56$ for beak depth; $F(2,90)=1.69, P=0.19$ for weight $)$.

\section{Discussion}

This population and Darwin's Finches in general, have reduced growth rates (Boag 1984), and longer nestling periods (Grant and Grant 1980; Boag and Grant 1984) than finches in seasonal temperate environments. This suite of characters may be adaptively related to a predator-free environment in the Galápagos (Boag and Grant 1984). Parents are able to raise more, slowly-growing chicks by feeding each chick less food per day and, in the absence of nest predation the resulting longer nestling period is not detrimental. The quantity of food individual chicks receive may have given rise to the slower growth in Darwin's Finches, but this does not imply that growth rates would immediately respond to changing food abundance. Rates of tissue maturation will be affected by persistent selection pressures for slower growth, and this may limit any flexibitility in the growth rates of some characters (Ricklefs 1979).

Selection pressures arising from sib-sib competition may also affect growth rates (Werschkul and Jackson 1981; Ricklefs 1982). Sibs that grow to a genetically large size, and hence large in the nest also under good conditions (Table 6) may be at a metabolic disadvantage when food is short, providing parents do not actively discriminate in their favor when feeding the brood, as seems to be generally the case in birds (Richter 1984). If the reduced covariance between chick and adult weight in 1980 was real (Table 6), the genetically larger chicks were starving first. There is other evidence for selection against large chick size, particularly after fledging (Price and Grant 1984). Genetically larger chicks seem to show some lack of flexibility in their growth schedule, at least for skeletal characters such as beak depth (Tables 4-6) and their apparent starvation before smaller chicks may be a consequence of such unaltered growth. A failure of larger chicks to reduce their growth rate and thereby reduce energy requirements could arise out of strong selection for rapid maturation at other times, which may be as important as relative size in sib-sib competition.

A reduction in the rate of increase in mass is an inevitable consequence of food shortage. In some species which suffer large and temporary food shortages, such as House Martins, Delichon urbica, growth delays have been shown to be accompanied by metabolism of previously stored fat (Bryant 1975; O'Connor 1977). Darwin's finches do not store fat. As food supplies are steadily declining during times of starvation, with any increase due to rain likely to be delayed by several days, selection pressures arising out of temporary food shortages are probably absent.

Rainfall and/or food abundance at the time of egg-formation may be a reasonable indicator of conditions for raising nestlings, and this is the situation under which clutch size is expected to vary adaptively (O'Connor 1977). A correlation between rainfall and clutch size is observed both in this species, and its sympatric congener, the Cactus Finch, Geospiza scandens (Millington and Grant 1984). However, judging from the number of chicks raised during poor conditions, the optimum clutch size would have often been less than two; and there was no advantage to laying eggs at all in three of the breeding periods, when none of the raised young survived for more than a month. In contrast the actual clutch size, at least for experienced females, never fell below three eggs (Table 1). The large disparity between observed and optimal clutch sizes suggests that the association of clutch size with environmental conditions may simply be a consequence of the conditions at the time of egg formation. Females presumable lay clutches even when conditions are poor because sometimes rain falls again and food conditions improve prior to the hatching and fledging of chicks.

A given level of hatching asynchrony could always be present in a population, with elimination of late hatching chicks only occurring if insufficient food is being brought to the nest (Lack 1968; Howe 1976, 1978; Hahn 1981; Zach 1982; Richer 1984). However, the degree of synchrony can also vary with environmental conditions. Tits, Parus spp., often show hatching asynchrony of second broods at a time when food supply is declining (Gibb 1950). Since their first broods hatch synchronously, it is probably disadvantageous for parents to hatch broods asynchronously 
when food is abundant: smaller chicks may suffer from crowding by their larger sibs (Clark and Wilson 1981). Similarly, the high degree of synchrony in Darwin's finches may prevent loss of late hatching chicks. Facultative asynchrony under poor conditions may not have evolved because there is a very restrictive set of conditions under which less than a complete brood could be successfully raised, and survive to breed. Such conditions, such as additional rain soon after fledging, have yet to be observed on Daphne (e.g. Fig. 1). Indeed, there was no advantage to raising even a single chick during three periods of food shortage in this study, since the few fledglings which reached independence died soon after. In these conditions hatching synchrony could be selectively favored as a means of ensuring rapid whole-brood loss.

To summarise, in the Galápagos environment, selection pressures for the reproductive flexibility to raise one or a few young in poor conditions may be small or absent. Further, any such selection, particularly as it affects growth rates and hatching synchrony, may be opposed by selection pressures operating when reproductive success is high. Recruits into the breeding population have only come from periods of relatively high overall breeding success.

Acknowedgements. I thank Ayse Unal and Spike Millington for help in the field, and Dave Anderson, Lisle Gibbs, Peter Grant and Dolph Schluter for comments on the manuscript. The research was funded by NSF grants DEB-77-23377 and DEB-79-21119 to P.R. Grant, with some additional support from the Chapman Fund. I thank the Dirección General de Desarrollo Forestal, Quito, and the National Park Service, Galápagos for permission to work on Daphne, and the Charles Darwin Research Station for logistic support.

\section{References}

Boag PT (1984) Growth and allometry of Darwin's finches (Geospiza) on Isla Daphne Major, Galápagos. J Zool (London) 204:413-441

Boag PT, Grant PR (1984) Darwin's Finches (Geospiza) on Isla Daphne Major, Galápagos: breeding and feeding ecology in a climatically variable environment. Ecol Monogr 54:463-489

Bryant DM (1975) Breeding biology of House martins Delichon urbica in relation to aerial insect abundance. Ibis 117:180-216

Bryant DM (1978) Establishment of weight hierarchies in the broods of house martins Delichon urbica. Ibis 120:16-26

Burley N (1980) Clutch size and clutch overlap: alternative and complementary reproductive tactics. Am Nat 115:223-246

Clark AB, Wilson DS (1981) Avian breeding adaptations: hatching asynchrony, brood reduction and nest failure. Quart Rev Biol $56: 253-277$

Falconer DS (1981) Introduction to quantitative genetics. 2nd edition. Longman, New York
Gibb J (1950) The breeding biology of the Great and Blue titmice. Ibis $92: 507-539$

Gibbs HL, Grant PR, Weiland J (1984) Breeding of Darwin's finches at an unusually early age in an El Nino year. Auk 101:872-874

Grant PR, Boag PT (1980) Rainfall on the Galápagos and the demography of Darwin's finches. Auk 97:227-244

Grant PR, Grant BR (1980) The breeding and feeding characteristics of Darwin's finches on Isla Genovesa, Galápagos. Ecol Monogr 50:381-410

Hahn DC (1981) Asynchronous hatching in the Laughing Gull cutting losses and reducing rivalry. Anim Behav 29:421-427

Horsfall JA (1984) Food supply and egg mass variation in the European Coot. Ecology 65:89-95

Howe HF (1976) Egg size, hatching asynchrony, sex, and brood reduction in the Common Grackle. Ecology 57:1195-1207

Howe HF (1978) Initial investment, clutch size, and brood reduction in the Common Grackle (Quiscalus quiscula L.). Ecology 59:1109-1122

Lack D (1968) Ecological adaptation for breeding in birds. Methuen, London, England

Millington SJ, Grant PR (1983) Feeding ecology and territoriality of the Cactus Finch Geospiza scandens on Isla Daphne Major, Galápagos. Oecologia (Berlin) 58:76-83

Millington SJ, Grant PR (1984) The breeding ecology of the Cactus Finch Geospiza scandens on Isla Daphne Major, Galápagos. Ardea 72:177-188

O'Connor RJ (1977) Growth strategies in nestling passerines. Living Bird 16:209-238

Price TD (1984a) The evolution of sexual size dimorphism in Darwin's fisnches. Am Nat 123:500-518

Price TD (1984b) Sexual selection on body size, plumage, and territory variables in a populaton of Darwin's finches. Evolum tion 38:327-341

Price TD, Grant PR (1984) Life history traits and natural selection for small body size in a population of Darwin's finches. Evolution 38:483-494

Price TD, Grant PR (1985) The evolution of ontogeny in Darwin's finches: a quantitative genetic approach. Am Nat 125:169-188

Richter WE (1984) Nestling survival and growth in the Yellowheaded blackbird Xanthocephalus xanthocephalus. Ecology 65:597-608

Ricklefs RE (1965) Brood reduction in the Curve-billed Thrasher. Condor 67:505-510

Ricklefs RE (1968) Patterns of growth in birds. 110:419-451

Ricklefs RE (1976) Growth rates of birds in the humid New World tropics. Ibis 118:179-207

Ricklefs RE (1979) Adaptation, constraint, and compromise in avian postnatal development. Biol Rev 54:269-290

Ricklefs RE (1982) Some considerations on sibling competition and avian growth rates. Auk 99:141-147

Werschkul DB, Jackson JA (1979) Sibling competition and avian growth rates. Ibis $121: 97-102$

Zach R (1982) Hatching asynchrony, egg size, growth and fledging in tree swallows. Auk 99:695-700

Received August 1, 1984 